\title{
Slang in animated cartoons: Translation peculiarities
}

\author{
Kateryna Bondarenko \\ Volodymyr Vynnychenko State Pedagogical University, Ukraine
}

\begin{abstract}
The research focuses on analysing the function of slang in modern cartoons (Madagascar 2, Kung Fu Panda, Shrek, Open Season, Cars) as well as translation strategies used to convey accurate meaning. Our data from film scripts (163 examples containing slang terms) has proved that slang, as an important part of cartoons' verbal component, should be and mainly retained in translation. Excerpts from original cartoons scripts show slang use, that may function both for the protagonists' characterisation and for the mapping of humor (carnivalesque) world picture. Componential analysis of meaning - breaking down the sense of slang terms into their minimal distinctive features - was used to determine the meaning of lexemes and reconstruct semantic domains actively verbalised by slang.

The assumption has been made that due to the universality of domains slang can be potentially translated in most cases. Componential analysis is particularly applicable to semantically related lexemes (in one language or comparable ones).

A thorough analysis of slang translation showed the employment of the following strategies: stylistic compensation (50.3\%), literal translation (44.7\%), omission (4.9\%) and cultural equivalence (0.1\%). As seen, a substantial proportion of the slang words can be translated from English into Ukrainian without significant loss of meaning. The neutralisation of slang appears to be inevitable in some cases.
\end{abstract}

Keywords: slang, carnivalesque, translation strategy

\section{Introduction}

Slang is often seen as a linguistic phenomenon that is unsuitable for translation. Due to sociolinguistic variables and pragmatic functions slang terms are often thought of as belonging to a restricted group that shares a common experience (Balabin 2002; Hudmanyan, Pletenets'ka 2014). According to Adams (2012), "Slang is biologically based because all of our cognitive abilities are in the brain and slang is a product of those abilities, the potentials, drawn out by social interaction" (Adams 2012: XIII). Let us consider, for instance, the following slang term and its translation into Ukrainian (from the source and target script of Cars):

(1) ST: You are dead, farm girl?

ТТ: Гаплик, село неасфальтоване! 
In English slang, farm girl in the source text (ST) means 'an independent female who has grown up on a farm and can drive anything with four wheels'. It may acquire the extra meanings of 'simplicity', 'modesty', 'unpretentiousness'. The Ukrainian concept of a village girl is mainly verbalised using slang terms with core elements 'female' and 'rural', sometimes implying narrowmindedness or vulgarity as in бичка, маланка etc. The suggested in the target text (TT) село неасфальтоване lacks 'female' and 'driving' semes yet may serve as a partial equivalent due to its relation to rural life and a 'naivety' connotation.

The reasons for using slang are universal: slang rebels against standard language through the use of terms not defined in standard language, making a conversation seem informal, suggesting 'insider-knowledge' with the people to whom you are speaking and displaying the speaker's attitude (Adams 2012). The basic concerns are consistent in slang as they do in much that is human: sex, money, intoxication, fear (of others), aggrandisement (of oneself) (Peters 2011). The following remark suits the modern understanding of slang:

\begin{abstract}
'Slang is the language that says no. Born in the street it resists the niceties of the respectable. It is impertinent, mocking, unconvinced by rules, regulations and ideologies. It is a subset of language that since its earliest appearance has been linked to the lower depths, the criminal, the marginal, the unwanted or even persecuted members of society. It has been censored, ignored, shoved to one side and into the gutter from where it is widely believed to take its inspiration and in which it and its users have a home. It remains something apart, and for many that is where it should stay.'
\end{abstract}

Green (2014: 6)

With regard to the complexity of the linguistic phenomena the concept of P. Newmark is chosen for the analysis. Newmark's idea was that the translator should decide how much attention he has to pay to the target language readers. This attention can partially be explained by the function of the text: the expressive, the informative and the vocative. The core of the vocative function of language is the addressee who is called upon to act, think or feel, or in a word, to react in the way intended by the text (Newmark 1991). We believe that while watching the cartoon the recipient is expected to have fun first of all but quite often we find an implicit or explicit ideological framework, for example, representing political regimes or "Dreamworkification" in Shrek (Nieguth \& Lacassagne 2011). As Newmark (1991) points out, "The first factor in all vocative texts is the relationship between the writer and the readership. The second factor is that these texts must be written in a language that is immediately comprehensible to the readership. Vocative text requires "communicative" approach, while the expressive text a "semantic" one. Cartoons translation can be approached to both communicatively and semantically due to expressivity, ideology and polysemiotic character of the data (Newmark 1991: 41).

One should also take into consideration the polysemiotic nature of audiovisual texts when the issues of space and time accompany the shift from one language and culture to another (Gottlieb 1994). E. Mattielo indicates that most difficulties arise because the translation requires a lot of effort to find similar modes of expression for parallel social sets (Mattielo 2007). The potential possibility to achieve semantic equivalence is based on several assumptions: all languages have equal value, and different genius; everything can be translated from one language into another due to broad communality; there are no sacred or special languages and 
therefore, all languages have the same limitations and rules (Nida, Taber 2003). The semantic approach is used in this research since to trace strategies for the translation of slang in spoken dialog (Hamaida 2006).

This study will focus on the use of slang in five contemporary cartoons: Madagascar 2, Kung Fu Panda, Shrek, Open Season, Cars, as well as on its translation into Ukrainian. The objectives of the research are: to identify the slang functions in the source text and describe the translation strategies applied in the target text.

To achieve the research aims, all slang words and phrases from Madagascar 2, Kung Fu Panda, Shrek, Open Season, Cars scripts (163 examples containing slang terms) were defined with the help of The New Partridge Dictionary of Slang and Unconventional English (Partridge 2006). They were classified according to shared and differentiating features (semes). Breaking down the sense of a word into its minimal distinctive features was particularly important both for determining the meaning of the lexemes and for detecting the corresponding semantic groups. Furthermore, the Ukrainian scripts of the films were used to compare the SL dialogues regarding slang terms of the films with their given translation.

The qualitative descriptive method was used to meet the objectives of the research. The slang expressions are marked, classified according to semantic ideographic principles, selected and analysed with regard to slang theory and translation strategy theory (Ulvydiene \& Abramovaitè 2012).

\subsection{The data}

\subsubsection{Slang functions in animated cartoons}

Ontologically, slang's coinage and circulation comes rather from the wish of the individual to distinguish himself through oddity or grotesque humor (Hotten 1972). Slang acts as a linguistic means liberating carnivalesque laughter (Yelistratov 1995). A carnivalesque worldview presupposes the mocking of the dominant value system and is a verbal revolt against hierarchy and restrictions (Bakhtin 1984).

'These occasions built a second world and a second life outside officialdom, a world in which all ... people participated more or less, in which they lived during a given time of the year. If we fail to take into consideration this two-world condition, neither ... cultural consciousness nor the culture ... can be understood. To ignore or underestimate the laughing people ... also distorts the picture of European culture's historic development.'

Bakhtin (1984: 6)

Cartoons present a substantial number of slang words and expressions that make a significant fragment of a carnivalesque world picture. 


\subsubsection{Slang as a means of characterising the protagonist}

The use of slang provides clues to the identity and personality of a character (Trudgill 2000). Dialects, accents and slang reflect communicative patterns that are believed to be prototypical for a given social group (Giles et al. 1991). Cartoon protagonists can be best identified and marked through their use of language. Slang elements constitute their dialogues serving as markers of their individuality. The fast, modern and "arrogant" sports car, Lightning McQueen, from the Cars movie is a good example of such a manner of speaking:

\section{ST: Hey, fellas, how do you think I'd look in Dinoco blue?}

TT: Гей, хлопиі, як мені буде в кольорах Дайнащось?

The word fella designating an attractive male implies that a handsome exterior mask an unintelligent or at least light-minded personality.

(3) ST: While I'm stuck here paving this stinkin' road, Chick's in California schmoozing Dinoco.

ТТ: Поки я кладу июю смердючу дорогу, Шик у Каліборнї клеїть Дайнощось!

The lexeme schmooze literally signifies 'to gossip; to chat, to engage in idle talk; to network; to persuade someone indirectly'. In the TT the translator adds a sexual implication as клеїmь meaning 'to take on a romantic or sexual partner'.

(4) ST: I'm in hillbilly hell! My IQ's dropping by the second!

ТТ: Я здохну в ивому Задрипанську. Я здурію!

Hillbilly hell is used for nominating a remote, rural area, isolated and somewhat out of touch with modern culture. The cartoon audiovisual settings add to the concept of an old-fashioned provincial town as compared with that of Lightning McQueen's dream city.

At the same time there exist certain patterns with regard to the protagonists' speech peculiarities. The trickster archetype is one of them (Bassil-Morozow 2013). The Trickster is an archetypal psychic structure of extreme antiquity. In his clearest manifestations, he is a faithful reflection of an absolutely undifferentiated human consciousness, corresponding to a psyche that has hardly left the animal level. The Trickster's most disquieting quality is his lack of consciousness. He does stupid things and gets himself into ridiculous situations. Although not evil, his unconsciousness and un-relatedness lead to outrageous behavior. The Trickster manifests a dichotomy of qualities; some seem superhuman while others are inferior to the average person. The Trickster crosses boundaries and confuses previously known distinctions. He is a troublemaker, trying to assist while also causing problems, a wanderer who wants to be free of the constraints of the collective, which only serve to bind and limit him (Jung 1969).

Mater from Cars - one of the slickers, whose suspension is a little rusty and whose crusty cabin has seen better times - Martin, the zebra from Madagascar, The Donkey from Shrek - are all characters that are perpetually talkative, supportive and never malicious, providing their friends (protagonists, as a rule) with both positive spins and hard but necessary truths in the face of adversity. The Trickster archetype is subject to the consequences of their own foolishness 
because they lack the ability to feel shame. However, with the Trickster's lack of shame, their tongue is not constrained and often moves us past limitations and assumptions that might otherwise restrain the society. In the cartoons, the Trickster usually acts as a help-mate and is substandard both in appearance and speech. For example, The Donkey (Shrek) is the friendly beast. He accompanies Shrek on his quest to rescue Princess Fiona. Also, Donkey helps Shrek by distracting the dragon for a while.

(5) ST: You're a mean, green, fightin' machine. Together we'll scare the spit out of anybody that crosses us.

ТТ: Ти - мужній зелений бойовик. Удвох ми залякаємо всіх, хто криво гляне!

(Shrek)

Fightin' machine refers to a person who is superior to others, having a wide knowledge in a certain field. The Donkey seems to be mocking Shrek's uncertainty and making himself a motivational pillar of support.

(6) ST: I'm the world's best backwards driver! ou just watch this right here, lover boy.

ТТ: Вріжусь? Тю! Та я - найкращий зник задом наперед. Осьо, дивись, як треба, ухажор!

(Shrek)

The dictionary definition suggests the idea of a lover boy as a sexually promiscuous man. In the context of this cartoon, the sports car attempts to attract a girl. The use of slang by tricksters and other characters should be viewed as a rebellion against narrow-mindedness and las a means of laying out beliefs that serve the core conflicts in the cartoons.

\subsubsection{Slang as a means of revealing the peculiarities of the environment}

In dealing with slang terms from all the cartoons, we encountered more than a just a mixture of them. We used slang term definitions from dictionaries for semantic decomposition to identify the domains mostly verbalised by slang terms. These domains are mainly relevant to human physiology, emotions and social life. Lexemes semantically related to the same domain have been listed together to build a semantic map (consisting of lexical-semantic groups) of the cartoons verbalised by slang words.

The primitive values that underlie slang are an integral part of humor culture; yet these reproductive, social, ego-instincts are seen as inappropriate, and consequently require extra lexicalisation. Slang is a language pulsating nerve, and unlike standard language, does not conform to political correctness rules and is free to nominate the realia-taboo. Its mechanisms correlate rather with primeval instincts ruled by "childishly simple-minded censors" (Freud 1928) than with civilized cultural layering. The primeval worldview preconditions special values ("forbidden wishes") - human survival and successful reproduction being the most valuable. The latter is perceived unconsciously but remains the core principle of slang.

The "Human being nominations (intellectual, intellectual-emotional, intellectualemotional-physical state, property, quality)" domain attracts $27.1 \%$ of slang terms detected.

(7) ST: Then why are you bringing him up, you lemon?

ТТ: Це тому ти привів його сюди, дурбецало!

(Cars) 
(8) ST: Mack? I ain't no Mack! I'm a Peterbilt, for dang sake! Turn on your lights, you moron! ТТ: Я - не Мак, я - Пітербілт, дурнику! Фари увімкни, дажак

(9) ST: You big tube, you numpty, you big lassie's blouse.

ТT: Придурок, маніяк, подушка диванна

(Madagascar 2)

The lexemes lemon, moron, tube denote 'a simple-minded fool', implicitly 'a despicable or contemptible person'. Ukrainian slang suggests a vast list of synonyms nominating fools, idiots, despicable people (придурок дурбеиало, лажак etc) - so all English slang terms can be successfully rendered into the TT without neutralising.

$22.43 \%$ of all slang terms detected belong to the "Human being nominations (physical, physiological, mental condition, gender, age)" domain:

(10) ST: The chicks love that romantic crap!

ТТ: Дівки люблять романтичну лажу

(Shrek)

(11) ST: Hey, fatso, shove off. You're snapping my spine here.

ТТ: Сунься, жиртрест, бо хребет мені розчавиш

(Madagascar 2)

The slang term chicks stands for 'young women, girls', fatso - for 'an obese person'. Their

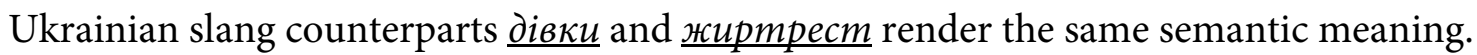

It should be mentioned that modern cartoons contain topics or elements that make the story much more adult than expected. The cartoons analyzed contain substandard language, pop culture references etc. Appealing to a more adult audience, despite the films gearing towards families, leads to adult topics appearing in the movies. Sexual relations are under discussion in almost all the cartoons analysed:

(12) ST: But, oh, he was a persistent little bugger for a two-cylinder.

ТТ: А він впертий був кавалер, та ще й двоииліндровий.

(Cars)

The word bugger signifies 'a regular fellow', but two-cylinder characteristics imply sexual power beyond the average. The Ukrainian slang term кавалер suggested in TT bears an extra seme of flirtation or love-making.

(13) ST: Don't worry. You can flirt around with Mr. Hot Pants after I'm gone.

TT: Фліртуватимеш з Трах-Трах, коли мене не буде.

The slang expression hot pants denotes sexual desire explicitly and is rendered by a full Ukrainian equivalent Tpax-Tpax, which is vulgar and obscene.

(14) ST: I like 'em big. I like 'em chunky. I like 'em big. I like 'em plumpy. I like 'em round. With something, something. They like my sound. They think I'm funky!

ТТ: Люблю великих, Люблю товстеньких, Люблю великих, Люблю пухкеньких, Люблю кругленьких, 3 таким такеньким, Що люблять співи, бо я - крутелик!

(Madagascar) 
The slang term funky is polysemantic and may stand for 'bad, distasteful, dirty, smelly, earthy, fundamental, emotional, fashionable'. In the context of the cartoon the term also implies sexuality that is neutralised in the translation (крутелик may stand for 'someone of excellence' but does not imply any sexual meaning).

The concept of sexual proactiveness implying promiscuity is also verbalised actively by slang terms like beast - 'a very unattractive woman, especially if sexually proactive'):

(15) ST: Oh, no. The woman-beast is torturing him again. That looks like fun!

TТ: Та твотя знову його катує!

(Madagascar 2)

As seen, slang terms used in the studied cartoons mainly belong to the domains related to physiology and social life. Successful human survival and breeding is perceived mostly unconsciously but remains the principle at the core of the studied phenomena essence. The primitive values underlie slang as an integral part of humor culture. The reproductive, social, ego-instincts are seen as inappropriate, and consequently become targets for slang terms concentrations in certain domains. The "Human body nominations" domain contains $9.35 \%$ of all the data.

(16) ST: Yeah, like when you beat me on the butt?

TТ: Він вкусив мене за дуny

(Kung Fu Panda)

(17) ST: Well, I have to save my ass.

TT: Мушу рятувати гузно.

(Open Season)

All the lexemes mentioned above refer to buttocks, so scenes from the movies do. The suggested Ukrainian дyna and гузно refer to the same denotate and are absolute equivalents to butt and ass. The following suggests slang neologism with the meaning of 'testicles' with the audiovisual setting contributing to the humoristic scene. In the target text the slang term is rendered explicitly with панденята 'baby pandas'.

(18) ST: My tenders.

TT: Мої панденята.

There is a fair amount of what can been termed body prejudice (pressure to be young, fit, with no evidence of any disability or disease or weakness in the body). The body serves as a universal domain for carnivalesque (humour culture) as such, and the slang terms nominating body and its functions are present in every living language.

'... the bodily element is deeply positive. It is presented not in a private, egoistic form, severed from other spheres of life, but as something universal, representing all the people. As such it is opposed to severance from the material and bodily roots of the world; it makes no pretense to renunciation of the earthy, or independence of the earth and the body. We repeat: the body and bodily life have here a cosmic and at the same time an all-people's character; this is not the body and its physiology in the modern sense of these words, because it is not individualized. The material bodily principle is contained not in the biological individual..., but in the people, a people who are continually growing and renewed... This exaggeration has a positive, assertive character. The leading themes of these images of bodily life are fertility, growth, and a brimming- 
over abundance. Manifestations of this life refer not to the isolated biological individual, not to the private, egotistic 'economic man,' but to the collective ancestral body of all the people.'

Bakhtin (1984: 18)

"Familiar, friendly, emotional address forms" domain lexemes make up $25.23 \%$ of all the data collected:

(19) ST: Look, pal, I don't know who you think you are!

ТT: Слухай, паиан, я не знаю, хто ти такий...;

(Cars)

(20) ST: Respect the classics, man. t's Hendrix!

ТT: Шануй класиків, цувак. Це - Хендрікс

(Cars)

(21) ST: Playtime is over, pal.

ТТ: Це добре, малий, та ігри закінчились.

(Cars)

The slang terms pal, man, dude, kid used as an affectionate term of address, are quite numerous and presumably lead a conversation towards informality. In the translation absolute equivalents (пацан, чувак, малий) are suggested.

The "Human being nominations with regard to social property, social status, activity, functions; personal and social relations, contacts" domain attracts $4.67 \%$ of all the data.

(22) ST: Is it true you've been in rehab? - Was McQueen your prisoner? - Shoot, no! We're best buds!

TТ: Вас що, тримали в полоні? Чи був МакКвін заручником? Тю, та ні!!! Ми - дружбаки!

(Cars)

The terms buds and дружбаки denotating 'a close friend' maintain the relation of semantic equivalence.

The "Abstract nouns: situations, actions, circumstances" domain attracts $6.55 \%$ of all the corpus analysed.

(23) ST: His magnificent antlers, a testament to his great prowess... ...his strength, his masculinity, his awesomeness! his super- incredible coolness! his amazing kick-butt-ocity!

ТТ: Його величні роги - свідоцтво його чоловічої доблесті, це - його сила, його мужність, його шикарність, його супер-неймовірна крутість, його здатність накрутити хвіст кому завгодно!

(Madagascar 2)

The slang term coolness implies the state of being of a higher standard and is equivalent to кpymicmb. The neologism kick-butt-ocity derived from to kick one's butt 'to defeat someone or something decisively' has the same meaning when rendered as the Ukrainian slang phrase накрутити хвіст with the same meaning.

The concept of slang suggested here is consistent with lexical theories that see words and word groups as cognitively structured and linked into networks. Personal lexicographic experience of compiling an English-Ukrainian slang dictionary based on semantic-ideographic principles shows the universality of basic semantic domains - slang in the contrasted languages is concentrated within the domains correlated with successful survival and human breeding (Бондаренко, Гась 2018). 
'It subscribes to nothing but itself - no belief systems, no true believers, no faith, no religion, no politics, no party. It is the linguistic version of Freud's id, defined by him in 1933 as 'the dark, inaccessible part of our personality $[\ldots]$ It is filled with energy reaching it from the instincts, but it has no organization, produces no collective will, but only a striving to bring about the satisfaction of the instinctual needs subject to the observance of the pleasure principle.' It is hardly surprising that in English slang it, translating id from the Latin and the original German, can mean sex or either of the bodily parts it requires for consummation. So be it.'

Green (2010)

The mentioned domains productivity is predetermined by a specific carnivalesque (humour) world mapping (Grace \& Tobin 2002; Gilmore 1998) with a heavy emphasis on sex, physiological and social deficiencies etc.

\subsubsection{Translation peculiarities}

As proved by many scholars, audiovisual translation tends to tone down substandard language and this mitigation is typical for children's films (Mattiello 2009). 163 specifically chosen segments in which slang terms appear in the source texts have been analysed in order to determine the frequency in the strategies the translators used. The semantic meaning of slang terms in the source text have been checked in The Concise New Partridge Dictionary of Slang and Unconventional English. The corresponding terms in the target text underwent semantic decomposition with the help of contemporary Ukrainian slang dictionaries (Stavyts'ka 2003; Kondratiuk 2006).

Among 163 slang translation cases the following translation strategies have been detected:

1) Stylistic compensation. Compensation is the most frequently used strategy in the translation of the animated cartoons as there are many slang terms and expressions that do not have absolute equivalents in the target language. $50.3 \%$ slang terms were neutralised or mitigated and translated by the standard terms with the same semantic meaning.

(24) ST: Pretty lousy friend I guess.

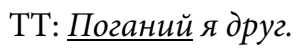

The adjective lousy refers to 'contemptible, shoddy, bad'. Because of the association with body lice, the term was deemed vulgar if not taboo in the US and is rendered in TT as nоганиц - with the general meaning of 'bad'.

(25) ST: He's really quite a chatterbox. Talk, you boneheaded dolt!

TТ: Це він соромиться, а так він страшне базікало. Балакай, телепню!

The slang term chatterbox means 'a very talkative person; conventionally contemptuous, but often affectionate'. In TT the translator uses базікало 'a talker' - a colloquial lexeme in Ukrainian. As seen absolute equivalence is not maintained. However, the border between slang and colloquial words and expressions is questionable, because certain slang words may pass into colloquial language and even further into standard speech (Cuddon 1991). 
As seen, the discussed source-target pairs mostly cover the same denotative meaning, the translator transfers the semantic content of the ST slang terms but does not convey the register. Standard terms suggested by the translators can be used in both formal and informal settings and do not seem to carry any attitude and consequently may lead to the losses of the cultural significance. In most cases the translator uses compensation when no equivalents are found in the target language. But there are certain concepts verbalised by sets of synonyms in Ukrainian slang, for instance those referring to effeminateness, weakness (тюфтель, дупка etc) or talkativeness (баклан, тріпло, тринділо еtс). Presumably mitigation cannot be explained by linguistic reasons only, but rather depends on factors outside the translators' team control, such as lip sync, time slots etc.

2) Literal Translation. $44.78 \%$ of the slang terms in the studied cartoons were translated literally - with semantic meaning maintained as well as the corresponding sociostylistic register. The present study shows that translators managed to render almost a half of ST slang terms into terms with the same level of formality in the TT.

(26) ST: Oops. I hate to be a party pooper Zuba!

ТТ: Не люблю бути кайфоломщиком, Зубо.

The expression party pooper has the meaning of 'a killjoy; a spoilsport' and is directly rendered by a Ukrainian slang term кайболомщик with exactly the same meaning.

(27) ST: Nobody goes AWOL on my watch.

ТT: Ніяких самоволок на моїи варті!

(Cars)

The terms $\underline{A W O L}$ and самоволка with the denotative meaning of 'absent without official leave' are absolute equivalents and used to be army jargon terms in the past.

3) Omission (4.9\%). Omission of slang may neutralise the negative effect and adapt the inappropriate words for the recipients. However, an identical effect can hardly be achieved then. Sometimes the omission is explained by some extralinguistic factors.

(28) ST: Crazy hot-rodder.

ТT: Ненормальний!

The absence of a Ukrainian counterpart for hot-rodder (successfully rendered in other episodes by гонщик) shows that translators should pay attention to the internal characteristics of audiovisual translation, in which parts of the original dialogue can be condensed or omitted.

4) Cultural equivalence (0.02\%)A paraphrasing strategy that results in cultural equivalence implies rendering realia absent or insignificant in the target culture. Their number is not that big due to the globalised market the cartoons are made for, but some realia are preserved and require domestification. 


\section{(29) ST: Fascist! Commie! \\ TT: $\underline{\text { Фauucm! }}$}

(Cars)

At the beginning of the $21^{\text {st }}$ century the concept of communism was not as negatively connotated in Ukraine as it used to be in the USA. The lack of connotation presumably led to omission in the translation. It should be noted that nowadays the translator would definitely retain the Commie factor with regard to the political situation changes (de-communisation) in Ukraine.

(30) ST: You need a little R and R. Recharge the old batteries. But you know, after a while, why didn't you go back? - I fell in love. - Oh. - Yep. - Corvette? - No. I fell in love with this.

ТТ: Іноді треба спинитись, підзарядити акумулятори. Але з часом? Чого ти не вернулась? - Я закохалась. - О! - Так. - Якийсь мерс? Ні. Я закохалась в ось ие.

(Cars)

Corvette cars are not very popular in Ukraine and consequently a direct equivalent lacks the connotation present in the source text. Ukrainian мерс (slang term denoting Mercedes car) stands for Corvette, because it has the connotative meaning 'of excellent quality, worth admiring' (may cause jealousy - as it does in the cartoon).

Slang is inherently linked to the socio-cultural setting within which a text is created, but its national specificity is usually neutralised in audiovisual products meant for broadcasting worldwide.

\section{Conclusions}

Slang has always been one of the most challenging linguistic phenomena for audiovisual translation since slang has always been linked to society and its verbal manifestation. As demonstrated in the study, slang terms are employed in the cartoons so as to identify characters, enhance the impression of informality and contribute to a carnivalesque (humour) world picture embodied in the cartoons. As for the Ukrainian translation of Madagascar 2, Kung Fu Panda, Shrek, Open Season, Cars the present study shows that stylistic compensation, literal translation, omission and cultural equivalence are the basic strategies used by the translators.

It is found that semantic equivalence achieved through the strategy of literal translation constitutes $44.78 \%$ of the time. As seen, regarding slang terms, one can transfer the same sociostylistic level of the source text into the target text without any major difficulties. An omission strategy constitutes only $4.9 \%$, proving that translators try to keep slang terms and not lose their impact and cultural significance.

The possible lack of acceptable equivalent slang terms in the TC is not the only reason for mitigating slang terms in translation. The internal characteristics of audiovisual translation often make translators use compensation strategies to achieve the result. To conclude, it can be safely suggested that a greater use of slang terms may be seen in the future as a way to compensate for the loss of other items in specific types of audiovisual texts. 


\section{References}

Adams, M. 2012. Slang: The people's poetry. Oxford University Press. Bondarenko, K, and S. Gas. 2018. Detabooing in dictionaries and translation. Bogucki Wydawnictwo Naukowe. Bakhtin, M. 1984. Rabelais and his World. Vol. 341. Indiana University Press. Balabin, V. 2002. Contemporary American Military Slang as a Translation Problem. K.: Logos. Bassil-Morozow, H. 2013. The trickster in contemporary film. Routledge. Cuddon, J. A. 1991. The Penguin Dictionary of Literary Terms and Literary Theory. London: Penguin Books. Freud, S. 1928. Humour. The International Journal of Psychoanalysis 9: 1-6.

Giles, H., Wilson, P., and A. Conway. 1981. Accent and lexical diversity as determinants of impression formation and perceived employment suitability. Language sciences 3(1): 91-103.

Gilmore, D. D. 1998. Carnival and culture: Sex, symbol, and status in Spain. Yale University Press.

Gottlieb, H. 1994. Subtitling: diagonal translation. Perspectives, Studies in Translatology 2: 101-121.

Grace, D. J., and J. Tobin. 2002. Pleasure, creativity, and the carnivalesque in children's video production. The arts in children's lives, 195-214. Springer Netherlands.

Green, J. 2010. What is slang. Retrieved from http://jonathongreen.co.uk/the-job/

Green, J. 2014. The Vulgar Tongue: Green's History of Slang. Oxford University Press, USA.

Hudmanyan, A., and Y. Pletenets'ka. 2014. Translation of Jargons, Slangs and Pejorative Vocabulary of American Feature Films. Naukovi zapysky [Nizhins'koho derzhavnoho universytetu imeni Mykoly Hoholya]. Ser.: Philolohichni nauky (3): 58-61.

Hamaida, L. 2006. Read my Lips: Gaps in meaning between spoken and subtitled dialog. MuTra 2006 -Audiovisual Translation Scenarios: Conference Proceedings.

Hotten, J. C. 1972. The Slang Dictionary. Rowman \& Littlefield Publishers.

Jung, C. G. 1969. Archetypes of the collective unconscious. In R. F. C. Hull (trans.). The collected works of C. G. Jung. 2nd ed., 3-41. Princeton, NJ: Princeton University Press.

Kondratiuk, T. 2006. Slovnyk suchasnogo ukrayinskogo slenhu. Kharkiv: Folio.

Mattiello, E. 2009. Difficulty of slang translation. Translation Practices: Through Language to Culture, 65-83.

Newmark, P. 1991. About Translation. Clevedon: Multilingual Matters Ltd.

Nieguth, T., and A. Lacassagne (eds.). 2011. Investigating Shrek: Power, Identity, and Ideology. Springer.

Nida, E. A., and Ch. R. Taber. 2003. The Theory and Practice of Translation. Leiden: Koninklijke Brill.

Partridge, E. 2006. The New Partridge Dictionary of Slang and Unconventional English: JZ (Vol. 2). Taylor \& Francis.

Peters, M. 2011. Screaming Yellow Zonkers! Green's Dictionary is the Bible of Slang. Culture magazine.

Stavyts'ka, L. 2003. Korotkyi slovnyk zhargonnoyi leksyky ukrayins'koyi movy. Kyiv: Krytyka.

Victor, T., and T. Dalzell. 2007. The concise new Partridge dictionary of slang and unconventional English. Routledge.

Trudgill, P. 2000. Sociolinguistics: An introduction to language and society. Penguin UK.

Ulvydienė, L., and B. Abramovaitè. 2012. Literary Style in Translation: Slang in JD Salinger's The Catcher in the Rye. Studies About Languages 20: 100-108.

Yelistratov, V. S. 1995. Argo i kultura [Argot and Culture]. Moscow, Moscow State Univ. Publ. 